\title{
STUDI STILISTIKA TERHADAP TONGKAT NABI MUSA DI DALAM AL-QUR'AN
}

\author{
Najihatul Abadiyah Mannan \\ MD Raudhatul Athfal Pamekasan, \\ Email: najihatulabadiyah7@gmail.com
}

\begin{abstract}
Abstrak:
Al-Qur'an menggunakan tiga lafal yang berbeda dalam mengungkapkan makna ular yang terdapat dalam kisah Nabi Musa, yakni hayyah, tsu'bân dan jânn. Di satu sisi al-Qur'an menjelaskan bahwa tongkat Nabi Musa berubah menjadi ular yang sebenarnya (QS. al-A'râf [7]: 107). Sementara di sisi lain, tongkat tersebut, disebutkan, berubah menyerupai ular (QS. al-Naml [27]: 10). Penelitian ini bertujuan mengungkapkan hakikat tongkat Nabi Musa, mengkaji lafal 'ashâ dan lafal-lafal lain yang bermakna ular dalam kisah Nabi Musa beserta implikasinya berdasarkan teori diksional-leksikal. Diksional-leksikal merupakan salah satu cabang stilistika di mana diksional adalah pemilihan kata yang sesuai agar cocok dengan konteks yang dijelaskan, sedangkan leksikal adalah makna dasar suatu kata. Penelitian ini menggunakan pendekatan stilistik dan termasuk penelitian tematik konseptual. Hasil penelitian menunjukkan bahwa tongkat Nabi Musa pada hakikatnya adalah sebuah kayu bersifat keras dan kokoh sehingga dapat membantunya dalam hal apapun. Al-Qur'an memilih diksi 'ashâ karena istilah tersebut merujuk pada tongkat yang memang digunakan sebagai tumpuan ketika berjalan. Diksi tsu'bân, sebaliknya, dipilih ketika Musa menunjukkan kekuasaan Allah di hadapan Fir'aun karena diksi tersebut (makna leksikal: sâla/jarâ) bermakna ular jantan yang besar, gemuk dan panjang tapi tidak gesit. Sementara itu, ketika menerima mukjizat di Bukit Sinai, al-Qur'an memilih diksi hayyah karena ia termasuk jenis ular yang besar dan gesit) dan jânn (ular kecil tapi gesit; makna leksikal: satr), karena perubahan tongkat tersebut tertutup dari keramaian manusia. Lafal tsu'bân bersanding dengan mubîn karena merujuk pada ular berbentuk aliran air yang melata ke dalam lembah dan terlihat jelas di hadapan Fir 'aun, sementara lafal hayyah bersanding dengan tas'â karena ular tersebut berjalan dengan gesit dan mencari kehidupan. Adapun lafal jânn bersanding dengan tahtazzu karena ular tersebut mempunyai gerakan gesit. Lafal jânn menjadi bayân lafal hayyah dalam kegesitannya karena dua lafal tersebut digunakan dalam satu peristiwa. Ini menunukkan bahwa tongkat Nabi Musa benar-benar berubah menjadi ular, bukan menyerupai ular.
\end{abstract}

Kata Kunci: Tongkat; Ular; Stilistika; Diksional-Leksikal 


\section{Najihatul Abadiyah Mannan}

\section{PENDAHULUAN}

Al-Qur'an sebagai kitab suci memiliki karakteristik yang berbeda dibanding kitab samawi yang lain. Salah satu karakteristik al-Qur'an adalah gaya bahasa dan sastra yang indah serta ekspresi puitisnya yang unik jika dikaji dalam aspek stilistika. Sebagaimana yang dikutip oleh Wahyu Hanafi dalam artikelnya, Ragam Gaya Bahasa Ayat-ayat Thalab dalam Diskursus Stilistika, Nurcholish Madjid mengungkapkan bahwa al-Qur'an memang tidak sama dengan uslûb bahasa Arab harian, bahkan dengan bahasa sunnah pun berbeda. Pandangan bahwa Bahasa Arab sebagai bahasa al-Qur'an lebih merupakan soal teknis penyampaian pesan daripada nilai tersebut ditunjang oleh keterangan al-Qur'an bahwa Nabi Muhammad saw. adalah orang Arab, maka mustahil Allah mewahyukan ajaran-Nya dalam bahasa nonArab. ${ }^{1}$

Sebagian besar bagian Al-Qur'an berisi kisah kaum terdahulu. Kisah dalam al-Qur'an dimuat dalam 35 surah dan sebanyak 1600 ayat. Dalam kisah itu, gaya bahasa yang digunakan bervariasi. Perintah ataupun ajaran moral disampaikan secara tidak langsung sehingga pesan yang disampaikan kepada manusia sebagai sasaran kisah ini akan lebih mengena. Akan tetapi, ayat yang hampir mendominasi isi al-Qur'an ini kurang mendapat perhatian dari para peneliti dibanding perhatian mereka terhadap ayat hukum dan teologi. ${ }^{2}$

Kisah Nabi Musa, misalnya. Dalam al-Qur'an, kisah tersebut tersebar di berbagai surah menggunakan bahasa yang berbeda namun isinya sama. ${ }^{3}$ Akan tetapi, ada juga ayat yang mengisahkan Nabi Musa dengan bahasa yang mirip bahkan sama. Ketersebaran kisah Musa dalam al-Qur'an tidaklah sama; adakalanya kisah Musa dengan kronologi berbeda, tokoh yang berbeda bahkan dengan gaya bahasa yang berbeda. ${ }^{4}$

Mukjizat Nabi Musa yang diulang-ulang oleh al-Qur'an sebanyak sembilan kali ${ }^{5}$ hanya ada dua, yakni berubahnya tongkat menjadi seekor ular serta keluarnya cahaya dari tangan Nabi Musa setelah diletakkan kemudian dikeluarkan dari ketiaknya (janâh). Dari kedua mukjizat tersebut, mukjizat yang lebih menonjol dan menarik adalah berubahnya tongkat ('ashâ) menjadi ular. Al-Qur'an menggunakan lafal yang berbeda dalam mengungkapkan makna ular dalam kisah Nabi Musa. Selain itu, al-Qur'an menggunakan kata 'seperti' ketika mengisahkan berubahnya tongkat menjadi ular. Ini tampak dalam QS. al-Naml [27]: 10,

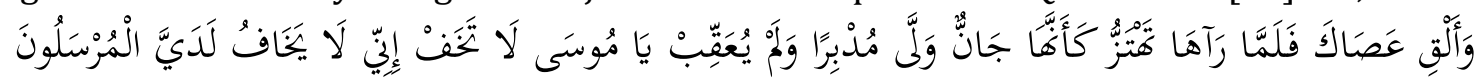

"Dan lemparkanlah tongkatmu! Maka tatkala (tongkat itu menjadi ular) Musa melihatnya bergerak-gerak seperti ia seekor ular yang gesit, larilah ia berbalik ke

\footnotetext{
1 Wahyu Hanafi, Ragam Gaya Bahasa Ayat-ayat Thalab dalam Diskursus Stilistika (Ponorogo: IAI Sunan Giri, 2015), hlm. 37.

2 Syihabuddin Qalyubi, Stilistika Al-Qur'an: Makna di Balik Kisah Ibrahim (Yogyakarta: LKiS, 2009), hlm. ix.

${ }^{3}$ QS. al-A'râf [7]: 107, QS. al-Syu'arâ' [26]: 32, QS. Thâhâ [20]: 20, QS. al-Hijr [15]: 27, QS. an-Naml [27]: 10 dan QS. al-Qashash [28]: 31.

4 Mursalim, "Gaya Bahasa Pengulangan Kisah Nabi Musa as dalam al-Qur'an: Suatu Kajian Stilistika”, Jurnal Lentera, Vol 1, (Juni, 2017), hlm. 94-100.

${ }^{5}$ QS. al-A'râf [7]: 107, 108 dan 117, QS. al-Syu'arâ' [26]: 32 dan 45, QS. Thâhâ [20]: 20 dan 22, QS. an-Naml [27]: 10 dan QS. al-Qashash [28]: 31.
} 
belakang tanpa menoleh. "Hai Musa, janganlah kamu takut. Sesungguhnya orang yang dijadikan rasul, tidak takut di hadapan-Ku."6

Secara tekstual, ayat di atas terlihat kontradiktif dengan ayat lain yang menjelaskan bahwa tongkat Nabi Musa berubah menjadi ular yang sesungguhnya, yakni dalam QS. al-A'râf [7]: 107. Adanya kontradiksi tersebut menjadi menarik untuk dikaji dengan pendekatan stilistika. Menurut Nyoman Kutha Ratna dalam bukunya, Stilistika Kajian Puitika Bahasa, Sastra dan Budaya, sumber penelitian stilistika adalah semua jenis komunikasi yang menggunakan bahasa, baik bahasa lisan ataupun bahasa tulisan. ${ }^{7}$ Obyek kajian stilistika begitu luas hingga meliputi hampir semua fenomena kebahasaan. ${ }^{8}$ Stilistika merupakan ilmu yang mempelajari cara bertutur seperti, fonologi ${ }^{9}$, sintaksis ${ }^{10}$, polisemi11, tikrâr al-Qur'ân ${ }^{12}$, gaya bahasa retoris ${ }^{13}$, gaya bahasa kiasan ${ }^{14}$ dan diksional-leksikal.15

6 Departemen Agama, Bukhara al-Qur'an Tajwid dan Terjemah (Bandung: Sygma Examedia Arkanleema, 2010), hlm. 377.

7 Nyoman Kutha Ratna, Stilistika Kajian Puitika Bahasa, Sastra dan Budaya, cet-2 (Yogyakarta: Pustaka Pelajar, 2014), hlm. 13.

8 Zubair, Stilistika Arab: Studi Ayat-Ayat Pernikahan dalam Al-Qur'an (Jakarta: Amzah, 2017), hlm. 3.

9 Fonologi ialah ilmu dalam bidang linguistik yang menyelidiki bunyi-bunyi bahasa menurut fungsinya. Departemen Pendidikan Nasional, Kamus Besar Bahasa Indonesia Pusat Bahasa, edisi ke-4 (Jakarta: Gramedia Pustaka Utama, 2008), hlm. 396. Dalam stilistika al-Qur'an, yang paling banyak mengandung fonologi adalah bunyi akhir pada ayat dalam satu surat. Sayuti menjelaskan bahwa fonologi adalah lawan dari fonetik. Jika fonetik adalah cabang ilmu bunyi yang tidak memerhatikan fungsi dan makna bunyi, maka fonologi adalah ilmu bunyi yang membahas tentang bunyi bahasa tertentu dengan mempertimbangkan fungsi dan makna yang dikandungnya. Ahmad Sayuti Anshari Nasution, Fonetik dan Fonologi al-Qur'an (Jakarta: Amzah, 2012), hlm. 3

10 Sintaksis adalah cabang ilmu linguistik tentang susunan kalimat dan bagiannya. Sintaksis dapat disebut juga dengan ilmu tata kalimat dan pengaturan hubungan kata dengan kata. Dalam Bahasa Arab, ilmu ini disebut dengan ilmu nahwu. Departemen Pendidikan, Kamus Besar, hlm. 1315. Dalam stilistika al-Qur'an, pengaitan kata ini disebut dengan sintaksis.

${ }^{11}$ Polisemi adalah cabang ilmu linguistik yang membahas mengenai kata, frasa dan sejenisnya yang bermakna lebih dari satu. Polisemi berasal dari kata 'polisem'. Polisemi sendiri berarti ihwal polisem (keadaan polisem) atau proses pemaknaannya. Lihat, ibid., hlm. 1090.

12 Tikrâr al-Qur'ân adalah pengulangan yang tidak hanya satu kali, tetapi sampai beberapa kali

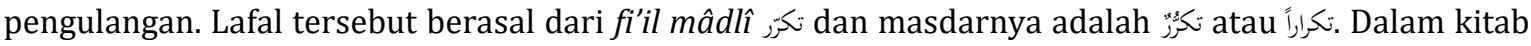
al-Mughnîy: Mu'jam al-Lughah al-'Arâbiyyah, ini dimaknai dengan إذا حصل مرارا. 'Abd al-Haq al-Kattânî, alMughnîy: Mu'jam al-Lughah al-'Arâbiyyah (Beirut: Dâr Kutub al-'Ilmiyyah, 2013), hlm. 427.

13 Gaya bahasa retoris adalah gaya bahasa atau keterampilan berbahasa yang secara efektif berkontribusi dalam karang-mengarang. Gaya ini juga merupakan seni dalam berpidato dengan isi pidato yang muluk-muluk dan bombastis. Departemen Pendidikan, Kamus Besar, hlm. 1171. Dalam stilistika al-Qur'an, gaya ini biasanya terdapat pada ayat ayat yang mengandung pernyataan mengenai janji atau ancaman Allah.

14 Gaya bahasa kiasan adalah gaya bahasa yang mengandung pertimbangan tentang suatu hal dengan perbandingan atau persamaan dengan hal lain. Gaya bahasa ini disebut juga dengan majas yang bermakna konotasi atau bermakna tidak atau bukan yang sebenarnya. Majas ini ada banyak macamnya. Lihat, ibid., hlm. 695. Dalam al-Qur'an, gaya ini banyak ditemukan di ayat-ayat kisah, baik kisah nabi atau kisah lainnya.

15 Diksional yakni pemilihan kata yang tepat dan selaras dalam penggunaannya untuk mengungkapkan gagasan sehingga diperoleh efek tertentu seperti yang diharapkan. Sedangkan leksikal adalah ilmu yang berkaitan dengan kata, kosa kata dan leksem (satuan leksikal yang 


\section{Najihatul Abadiyah Mannan}

Pembahasan diksional-leksikal membuka kemungkinan untuk mengaitkan penelitian ini dengan prrinsip ada tidaknya sinonimitas (tarâduf) dalam al-Qur'an. ${ }^{16}$ Ini misalnya tampak dalam pengungkapan makna 'ular', al-Qur'an menggunakan lafal tsu'bân (ثعبان(17),

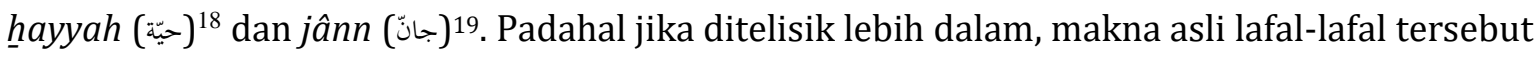
bukan ular, seperti lafal jânn yang makna aslinya adalah 'jin', kecuali lafal hayyah yang memang makna aslinya adalah 'ular'.20 Pemilihan dan penggunaan lafal dengan maksud tertentu itulah yang disebut dengan diksional.

\section{METODE PENELITIAN}

Penelitian ini merupakan penelitian pustaka (library research), yaitu dengan sumber data beberapa buku atau karya tulis ilmiah yang relevan dengan masalah atau fokus penelitian. Library research adalah kegiatan mengumpulkan, memeriksa dan menelusuri dokumen-dokumen atau kepustakaan yang dapat memberikan informasi atau keterangan yang dibutuhkan. Penulis menggunakan penelitian kepustakaan karena yang diteliti adalah literatur mengenai stilistika atau gaya bahasa (uslûb), khususnya gaya bahasa al-Qur'an.

Sumber data penelitian ini adalah dari al-Qur'an, kitab kebahasaan, karya ilmiah, buku yang membahas mengenai stilistika atau uslûb al-Qur'ân dan kisah Nabi Musa. Teknik pengumpulan data yang digunakan penulis adalah metode dokumentatif. Metode dokumentatif adalah mengumpulkan data primer yang diperoleh dari al-Qur'an. Setelah mengumpulkan data primer, penulis juga mengumpulkan data sekunder ${ }^{21}$ yang cukup relevan dengan fokus atau permasalahan penelitian.

Dalam metode penelitian al-Qur'an dan tafsir, penelitian ini merupakan penelitian tematik yang berjenis tematik konseptual. ${ }^{22}$ Pendekatan yang digunakan adalah stilistik

mendasari pelbagai bentuk kata). Departemen Pendidikan, Kamus Besar, hlm. 328 dan 805. Dalam stilistika al-Qur'an, diksional-leksikal berkaitan dengan kata sekaligus makna yang digunakan alQur'an. Mudjia Rahardjo menjelaskan bahwa leksikal termasuk linguistik murni bukan linguistik terapan. Leksikologi yang dimaksud adalah perbendaharaan kata. Mudjia Rahardjo dan Khalil, Sosiolinguistik Qurani (Malang: UIN Malang, 2008), hlm. 3

16 Raharjo, Sosiolinguistik Qurani, hlm. 3.

17 QS. al-A'raf [7]: 107 dan QS. al-Syu'ara' [26]: 32.

18 QS. Thâhâ [20]: 20.

${ }^{19}$ QS. al-Hijr [15]: 27, QS. al-Naml [27]: 10, QS. al-Qashash [28]: 31 dan QS. al-Raḥmân [55]: 15, 39, 56, dan 74. Namun, yang bermakna ular hanya pada QS. al-Naml [27]: 10 dan QS. al-Qashash [28]: 31.

20 Louis Ma'luf dan Bernard Tottel, al-Munjid fîy al-Lughah wa al-A 'lâm (Beirut: Dâr al-Machreq, 2002), hlm. 111.

21 Sumber data sekunder yang dimaksud adalah buku dan jurnal yang di dalamnya membahas stilistika, diksional-leksikal dan kisah beserta mukjizat Nabi Musa khususnya, bahkan membahas biografi Nabi Musa. Selain itu, tafsir al-Qur'an mengenai ayat kisah Nabi Musa, terutama dalam hal kemukjizatannya, juga menjadi sumber data sekunder dalam penelitian ini. Di antaranya adalah Stilistika al-Qur'an di Balik Kisah Nabi Ibrahim as karya Syihabuddin Qalyubi, Stilistika dalam Orientasi Studi al-Qur'an karya Syihabuddin Qalyubi, Stilistika Arab: Studi Ayat-Ayat Pernikahan dalam al-Qur'an karya Zubair, Stilistika Kajian Puitika Bahasa dan Sastra dan Budaya karya Nyoman Kutha Ratna, Diksi dan Gaya Bahasa karya Gorys Keraf, Kisah Para Nabi karya Ibnu Katsir dan literatur-literatur lainnya yang masih relevan dengan penelitian ini.

22 Dalam riset tematik, terdapat asumsi dasar bahwa ayat-ayat al-Qur'an ibarat untaian kalung emas yang satu rantai dengan rantai berikutnya terkait dan terkelindan. Adagium yang populer 
karena pemilihan kata dan makna yang dipakai dalam al-Qur'an merupakan gaya bahasa yang menjadikan al-Qur'an mempunyai nilai sastra yang lebih tinggi daripada karya sastra yang lain. Adapun lafal yang dikaji menggunakan teori stilistika adalah 'ashâ, tsu'bân, jânn dan hayyah.

Metode penyajian data dalam penelitian ini mengunakan deskriptif analitis/analisis isi (content analysis). Metode deskriptif adalah metode yang berupaya untuk menjelaskan masalah-masalah faktual. Metode ini bertujuan untuk memperoleh gambaran bahasa yang dipakai al-Qur'an dalam mukjizat Nabi Musa yang berupa tongkat. Kemudian, gambaran yang telah didapat tersebut dianalisis dengan data-data atau teori stilistika, khususnya diksionalleksikal, sehingga penulis dapat menyimpulkan dalam satu pemikiran yang utuh.

Untuk menganalisis data, penulis membuat langkah dan tahapan untuk memudahkan proses penelitian sehingga dapat menghasilkan temuan dan kesimpulan yang akurat. Langkah pertama adalah membaca data pokok yang bersumber dari data dokumenter atau data primer, yakni al-Qur'an. Data pokok tersebut adalah kisah Nabi Musa yang terletak di berbagai surah dalam al-Qur'an. Kedua, memahami kisah tersebut dalam bentuk teks secara kontekstual. Ketiga, memerhatikan dan mengumpulkan lafal yang bermakna sama, yaitu 'ular' dilihat dari segi terjemahan.

Keempat, menyebutkan secara detail jumlah pengulangan masing-masing lafal yang bermakna ular dalam al-Qur'an dan jumlah lafal yang bermakna 'tongkat' sebagai indikator terjadinya salah satu mukjizat Nabi Musa, yakni berubahnya tongkat menjadi ular. Kelima, mengkaji masing-masing lafal melalui pendekatan stilistika dengan dibantu oleh kamus, kitab atau referensi yang relevan. Keenam, membandingkan lafal tersebut satu sama lain untuk diketahui titik perbedaan yang mencolok antar lafal. Ketujuh, menjelaskan implikasi masingmasing lafal sehingga dapat digunakan dalam situasi dan konteks tertentu.

\section{Stilistika al-Qur'an dan Ranah Kajiannya}

Stilistika ('ilm al-uslûb) merupakan ilmu yang mengkaji bahasa dalam struktur tutur bahkan tutur itu sendiri. Kata uslûb jamaknya adalah asâlîb yang bermakna jalan yang membentang atau deretan barisan pohon kurma. Kata uslûb dalam Bahasa Arab mengandung makna jalan, wajah dan aliran, seperti orang Arab biasa mengatakan: أنتم في أسلوب السؤ (kalian أخذ فلان في : berada dalam jalan/aliran buruk). Kata uslûb juga berarti seni atau teknik. Contoh (gaya tutur si fulan dijadikan seni/teknik bertutur). ${ }^{23}$

Menurut Muththalib, uslûb merupakan jalan atau cara yang digunakan penulis untuk mengungkapkan atau mengekspresikan sesuatu yang ada dalam dirinya menjadi sebuah

dikemukakan oleh ulama adalah al-Qur'ân yufassir ba 'dluhû ba 'dlan.Penelitian tematik ini bervariasi, di antaranya tematik surat, tematik tokoh, tematik term dan tematik konseptual. Tematik surat adalah model kajian tematik dengan meneliti surat tertentu. Tematik term adalah model kajian tematik yang secara khusus meneliti term (istilah) tertentu dalam al-Qur'an. Tematik konseptual adalah model kajian tematik mengenai konsep-konsep tertentu yang secara eksplisit tidak disebut dalam al-Qur'an, tetapi secara substansial, ide tersebut ada dalam al-Qur'an. Tematik tokoh adalah model kajian tematik yang dilakukan melalui tokoh. Abdul Mustaqim, Metode Penelitian al-Qur'an dan Tafsir (Yogyakarta: Idea Press, 2015), hlm. 57-63.

${ }^{23}$ Syihabuddin Qalyubi, Stilistika dalam Orientasi; Studi al-Qur'an (Yogyakarta: Belukar, 2008), hlm. 21. 
karya yang konkret.24 Sedangkan stilistika (uslûbîyyah) adalah kajian bahasa terhadap style (uslûb) yang tertulis ataupun yang terucap. Namun, kajian stilistika ini lebih banyak digunakan atau diaplikasikan pada sastra tulis atau teks-teks kesusastraan.

Terkait dengan ini, Plato mengatakan bahwa terdapat karya yang memiliki gaya dan terdapat karya yang tidak memiliki gaya. Adapun Aristoteles mengatakan bahwa setiap karya memiliki gaya. Akan tetapi, terdapat karya yang memiliki gaya tinggi dan ada pula yang rendah; ada yang memiliki gaya kuat, ada pula yang memiliki gaya yang lemah; begitu pula ada yang memiliki gaya yang baik, tapi ada pula yang memiliki gaya yang jelek. ${ }^{25}$

Sementara itu, Gorys Keraf mengatakan bahwa konsep gaya (style) secara umum adalah cara mengungkapkan diri sendiri, baik menggunakan bahasa, tingkah laku, cara berpakaian dan semacamnya sehingga orang lain dapat menilai bahwa cara berpakaian, cara berjalan atau cara menulis seseorang berbeda dengan cara orang lain. Misalnya adalah gaya bahasa. Gaya bahasa dapat dilihat dari cara penggunaan bahasanya. Gaya bahasa dapat menilai pribadi, watak dan kemampuan seseorang dalam menggunakan bahasa sehingga semakin baik gaya bahasa seseorang, semakin baik pula penilaian orang lain terhadapnya dan begitu juga sebaliknya.

Dengan demikian, menurut hemat penulis, stilistika merupakan sebuah ilmu yang mempelajari atau memfokuskan pada kajian gaya bahasa yang digunakan seseorang baik berupa ucapan atau karya tulis. Kemudian, gaya bahasa tersebut menjadi sebuah ciri khas atau identitas seseorang atau sebuah karya tulis. Gaya bahasa itulah yang membuat sebuah ucapan atau karya tulis menjadi lebih hidup dan mempunyai nilai estetik yang berbeda dengan yang lain.

Kaitannya dengan ini, Al-Qur'an disebut sebagai kitab sastra terbesar. Semakin alQur'an dikaji, maka semakin nampak pula keindahannya. Maka, stilistika al-Qur'an menurut Qalyubi adalah ilmu yang menyelidiki bahasa yang dipergunakan dalam al-Qur'an. ${ }^{26}$ Sedangkan menurut Akhmad Muzakki dalam bukunya Stilistika al-Qur'an, stilistika al-Qur'an sebenarnya tidak akan terlepas dari i'jâz al-Qur'ân. ${ }^{27}$

Al-Qur'an sebagai kitab suci yang berbentuk teks dapat dijadikan sebagai obyek kajian stilistika karena mengandung gaya bahasa yang indah. Gaya bahasa yang digunakan alQur'an termasuk kategori uslûb mu 'aqqad dan uslûb adâb karena substansi yang terkandung dalam al-Qur'an tidak sederhana sebagaimana yang termaktub dalam terjemahannya dan setiap lafal beserta kalimatnya mengandung makna istimewa dan luar biasa. Karena itulah, muncul berbagai tafsir terhadap al-Qur'an, baik versi sufi, falsafi, hukmîy atau fiqhîy. 28

Muzakki dan Qalyubi mempunyai pandangan yang sama mengenai ranah kajian stilistika. Dari sekian banyak ranah kajian yang disebutkan para tokoh sebelumnya, dua tokoh ini hanya menyebutkan empat ranah kajian saja namun mencakup semuanya. Empat ranah kajian tersebut adalah 1) Al-ashwât (fonologi); 2) Ikhtiyâr al-lafzh (Preferensi kata); 3)

\footnotetext{
${ }^{24}$ Muhammad 'Abd al-Muththalib, Adabîyât: al-Balâghah wa al-Ushlûbîyah, cet-1 (Mesir: al-Syirkah al-Mishrîyah al-'Âlamîyah, 1994), hlm. 226.

25 Gorys Keraf, Diksi dan Gaya Bahasa (Jakarta: Gramedia Pustaka Utama, 2006), hlm. 112-113.

${ }^{26}$ Qalyubi, Studi al-Qur'an, hlm. 63.

27 Akhmad Muzakki, Stilistika al-Qur'an: Gaya Bahasa al-Qur'an dalam Konteks Komunikasi (Malang: UIN Malang, 2009), hlm. 16.

28 Syihabuddin Qalyubi, 'Ilm al-Uslûb Stilistika Bahasa dan Sastra Arab (Yogyakarta: Karya Media, 2013), hlm. 9.
} 
Ikhtiyâr al-jumlah (preferensi kalimat); 4) Al-inhirâf (deviasi), seperti iltifât, majâz dan bagian yang lain yang mempunyai pengaruh terhadap makna yang ditimbulkan. ${ }^{29}$

Dari sekian banyaknya persepsi mengenai ranah kajian stilistika, penulis hanya akan menjelaskan bagian-bagian sebagai berikut:

\section{Pertama, Preferensi Kata (ikhtiyâr al-lafzh)}

Dalam Bahasa Arab, preferensi menggunakan kata ikhtiyâr yang bermakna pilihan. ${ }^{30}$ Preferensi kata juga disebut diksi (pilihan kata) atau dalam istilah yang digunakan penulis adalah diksional. Ragam lafal atau kata dalam al-Qur'an banyak sekali, sehingga diperlukan klasifikasi secara spesifik dengan tujuan memudahkan pembelajaran. Bagian preferensi kata masih dibagi menjadi beberapa cabang pembahasan. Di antaranya adalah kata yang berdekatan maknanya, polisemi, kata yang berlawanan maknanya, kata asing yang diserap alQur'an dan kata yang sesuai dengan konteks lawan bicara. ${ }^{31}$

Dalam hal ini, penulis memasukkan leksikal (makna dasar kata) sebagai sandingan dengan preferensi kata atau diksional, bukan termasuk ke dalam bagiannya. Ini karena sebenarnya leksikal merupakan bagian yang lain, bahkan leksikal banyak dibahas dalam ranah kajian semantik. Maksud penulis menyandingkannya dengan diksional adalah karena makna dasar kata juga menjadi alasan kata tersebut dipilih.

\section{Kedua, Preferensi Kalimat (ikhtiyâr al-jumlah)}

Preferensi kalimat adalah bentuk kalimat yang digunakan sebagai media untuk menyampaikan pesan sekaligus berpengaruh terhadap makna yang diungkapkan. Dalam bagian ini, preferensi kalimat juga disebut dengan sintaksis (struktur kalimat). Misalnya, pemakaian struktur jumlah fi 'lîyah (fi' 'il-fấ'il) atau jumlah ismîyah ${ }^{32}$ (mubtadâ'-khabar).

Dalam jumlah ismîyah, susunan kalimat tidak selalu tersusun sistematis mubtadô'khabar. Adakalanya susunan tersebut terbalik menjadi khabar-mubtadâ', sehingga disebut dengan khabar muqaddam-mubtadâ' muakhkhar. Contohnya adalah dalam QS. al-Kâfirûn [109]: 5. Masih banyak bentuk kalimat dalam al-Qur'an yang tidak disebutkan dalam penjelasan ini dan hanya disebutkan dalam penjelasan khusus mengenai sintaksis.

\section{Diksional-Leksikal dan Ranah Kajiannya}

Menurut Crina Herteg yang dikutip oleh Qalyubi, style sering didefinisikan berdasarkan pendekatan yang digunakan. Dalam linguistik, sumber utama yang melahirkan

\footnotetext{
${ }^{29}$ Muzakki, Stilistika al-Qur'an, hlm. 39 dan Qalyubi, Studi al-Qur'an, hlm. 59.

30 Ahmad Warson Munawwir, al-Munawwir Kamus Arab-Indonesia, cet-14 (Surabaya: Pustaka Progresif, 1997), hlm. 378.

31 Muzakki, Stilistika al-Qur'an, hlm. 47.

32 Jumlah ismîyah adalah susunan kalimat yang terdiri dari mubtadâ'-khabar. Susunan tersebut menunjukkan bahwa hubungan keduanya tetap berlangsung ( $t s u b \hat{t} t$ ) dan tidak terikat waktu. Contoh dalam QS. al-Baqarah: 2,

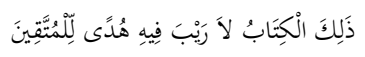

Kalimat di atas termasuk bentuk kalimat yang tersusun mubtada'-khabar. Hal ini menunjukkan bahwa al-Qur'an menjadi petunjuk bagi orang-orang yang bertakwa. Artinya, kedudukan al-Qur'an sebagai kitab yang tiada keraguan di dalamnya berlangsung terus menerus ( $t$ subût), tidak terbatas oleh waktu. al-Zarqânî, Manâhil al-'Irfân, hlm. 67.
} 
style adalah pilihan dan deviasi. Style merepresentasikan pilihan, dan pilihan dikondisikan oleh sumber serta konten bahasa. ${ }^{33}$ Ada beberapa ranah kajian dalam aspek ini. Akan tetapi, penulis hanya akan membahas dua ranah kajian yang begitu membantu penelitian ini.

\section{Kata yang Berdekatan Maknanya (Tarâduf)}

Istilah tarâduf atau sinonim untuk menyebut kata yang berdekatan maknanya masih diperdebatkan. Sibawaih (w. $180 \mathrm{H}$ ), seperti yang dikutip oleh Ibn Jinnî (w. 322 H), mendefinisikan tarâduf adalah ta'âdîy al-amtsilah wa talâqî al-ma'ânîy (lafal-lafal yang berbeda, tapi maknanya memiliki titik pertemuan). Adapun Fakhrur Razi mendefinisikan tarâduf dengan lafal-lafal yang menunjukkan pada sesuatu tertentu dengan sebuah ungkapan. ${ }^{34}$

Lebih jauh, masalah tarâduf juga memunculkan polemik berkelanjutan. Sedikitnya, terdapat dua kelompok mengenai adanya tarâduf dalam kebahasaan. Pertama, kelompok yang mengakui adanya tarâduf, seperti al-Rummânî, Fakhruddin al-Râzî dan al-Ashfihânî. Kedua, kelompok yang mengingkari adanya tarâduf, seperti Syahrûr, Tha'lab, Abû 'Alî alFârisî, Ibn Fâris dan Abu Hilal al-Askârî. ${ }^{35}$ Untuk menjembatani hal tersebut, Keraf membagi sinonim menjadi 4 ,

Pertama, Al-tarâduf al-kâmil/sinonim total dan komplet (complete synonymy). Sinonim jenis ini jarang adanya sehingga landasan inilah yang dijadikan hujjah untuk menolak adanya sinonim. ${ }^{36}$

Kedua, Syibh al-tarâduf/sinonim tidak total tapi komplet (near synonymy).

Ketiga, Al-taqârub al-dalâlî/sinonim total tapi tidak komplet (semantic relation).

Keempat, Istilzâm/sinonim tidak total dan tidak komplet (entailment).

Dalam penelitian ini, penulis lebih sependapat dengan kelompok yang kedua. Ini karena setiap penggunaan lafal dalam bahasa Arab, khususnya al-Qur'an, mempunyai leksem, tujuan, konteks dan asbâb al-nuzûl yang berbeda.

\section{Polisemi (Musytarak al-Lafdz)}

Secara etimologi, polisemi berasal dari dua kata, yaitu poly yang bermakna 'banyak' dan sema yang bermakna tanda. ${ }^{37}$ Terdapat beberapa versi dalam mengungkapkan musytarak al-lafzh. Muzakki menggunakan istilah polisemi, Qalyubi menggunakan istilah homonim, sedangkan Gorys Keraf membedakan antara polisemi dan homonim. Akan tetapi bagi penulis, antara polisemi dan homonim memiliki makna yang sama, yaitu satu bentuk kata atau lafal yang memiliki makna lebih dari satu. Perbedaannya adalah dalam makna terminologinya di mana homonim adalah lafal yang sifat dan ejaannya sama namun memiliki makna lebih dari satu.

${ }^{33}$ Qalyubi, Sastra Arab, hlm. 6.

34 Muzakki, Stilistika al-Qur'an, hlm. 47.

35 Ibid., hlm. 48-49.

36 Sinonim total adalah ketika dua kata dapat saling bertukar dalam semua konteks, sedangkan sinonim komplet adalah dua kata yang memiliki identitas makna kognitif dan emotif yang sama. Dalam hal ini, Gorys Keraf membagi jenis sinonim menjadi 4 bukan 5. Lihat, Keraf, Gaya Bahasa, hlm. 35.

37 Ibid., hlm. 36.6666 
Menurut Imel, semua lafal yang bersifat polisemi mempunyai makna yang hakiki bukan majâzi. Sedangkan 'Alî Hasballâh menyatakan bahwa polisemi terjadi karena perbedaan dialek dalam suatu bahasa serta perpindahan makna asal ke makna majâzi yang kemudian digunakan oleh banyak orang sehingga semuanya seakan menjadi makna hakiki. ${ }^{38}$ Demikian halnya yang terjadi dalam Bahasa Madura dan Bahasa Sasak. Kata geddhâng, misalnya, di Madura bermakna 'pisang' sedangkan dalam Bahasa Sasak, khususnya di Lombok, ia bermakna 'pepaya'.

\section{Hakikat Tongkat Nabi Musa dalam al-Qur'an}

Tongkat adalah sepotong bambu, rotan atau kayu yang agak panjang dan biasa digunakan untuk menopang, berjalan atau menyokong. ${ }^{39}$ Dalam kisah Nabi Musa, tongkat diungkapkan dengan lafal 'ashâ. Biasanya, lafal ini digunakan untuk menyebutkan tongkat kayu yang berfungsi sebagai tumpuan dalam berjalan dengan sifat dasarnya yang keras dan kokoh. ${ }^{40}$

Lafal cَ cَ bَ عَصَّ yang secara bahasa bermakna kayu. Maksudnya adalah batang kayu dari pohon yang telah digergaji kemudian disilangkan seperti salib. Secara substansial, 'ashâ adalah sesuatu yang panjang, kuat, kokoh dan keras seperti dua batang kayu (palang) yang ada pada mulut/lubang sumur. Keduanya sama panjang, kuat dan kokoh kemudian disilangkan satu sama lain. ${ }^{41}$ Dari situ, dapat dikatakan bahwa tongkat Nabi Musa pada hakikatnya adalah sebuah kayu panjang dan kokoh yang digunakan untuk segala keperluan atau kebutuhan Nabi Musa, baik berjalan, menggembala dan lain sebagainya.

Tongkat Nabi Musa menjadi mukjizat ketika ia menerima wahyu dari Allah di Lembah Thuwa. Ketika Nabi Musa mengikuti perintah Allah kemudian melemparnya, tongkat tersebut seketika menjadi ular yang besar dan menggeliat di tanah. Tongkat tersebut juga digunakan Nabi Musa untuk mengetuk pintu istana Fir'aun ketika akan masuk ke dalamnya. Setelah berdiri selama 2 tahun, barulah kemudian Fir'aun kaget mendengar ketukan itu. ${ }^{42}$

Selain digunakan untuk menggembala, tongkat yang bisa berubah menjadi ular tersebut juga digunakan Nabi Musa untuk menakut-nakuti Fir'aun dengan maksud memperlihatkan ayat atau bukti kerasulan dan kekuasaan Tuhan Musa, yakni Allah. ${ }^{43}$ Fir'aun ketakutan sekali hingga ia terkena diare 40 kali dalam sehari, padahal ia terbiasa buang air besar sekali dalam 40 hari. ${ }^{44}$

Lebih jauh, tongkat Nabi Musa tidak hanya bisa menjadi ular dalam kemukjizatannya. Ia juga bisa membelah lautan atas perintah dan izin Allah hingga membentuk jalan yang terbentang di tengahnya. 45 Berbeda dengan yang diutarakan Ibn Katsîr dalam kitabnya, Qashash al-Anbiyấ', diceritakan bahwa ketika Nabi Musa dan istrinya akan berpisah dengan Nabi Syu'aib, melalui sang istri, ia meminta kesediaan Nabi Syu'aib untuk memberi sebagian

\footnotetext{
${ }^{38}$ Qalyubi, Studi al-Qur'an, hlm. 80.

39 Departemen Pendidikan, Kamus Besar, hlm. 1479.

40 Ibnu Manzhur, Lisân al-'Arab, jilid 4 (Kairo: Dâr al-Ma'ârif, t.th), hlm. 2979.

41 Muhammad Hasan Hasan Jabal, al-Mu'jam al-Isytiqâqî al-Muasshal li Alfâzh al-Qur'ân al-Karîm, cet-1 (Kairo: Maktabah al-Adâb, 1923), hlm. 1472.

${ }^{42}$ Abu Fida', Kisah Para Nabi, hlm. 505.

${ }^{43}$ Hilmi, Nabi Musa, hlm. 87.

${ }^{44}$ Abu Fida', Kisah Para Nabi, hlm. 501.

45 Hilmi, Nabi Musa, hlm. 135.
} 
kambingnya sebagai bekal perjalanan menuju Mesir. Nabi Musa mendapat kambing yang belang kemudian ia mengambil tongkat dan bagian ujungnya dicabangkan. ${ }^{46}$

Sementara itu menurut riwayat Ibn 'Abbâs, tongkat Nabi Musa awalnya merupakan tongkat yang dianugerahkan malaikat kepada Nabi Syu'aib. Nabi Syu'aib lah yang kemudian memberikannya kepada Nabi Musa. Ketika itu, ia memerintahkan salah seorang putrinya untuk mengambil satu di antara tongkat-tongkatnya. Melihat tongkat yang dipilih sang putri, Nabi Syu 'aib berkata, "bukan yang itu. Berikan pada Musa yang lainnya saja."

Melihat kejadian itu, Nabi Musa bertekad mengambil tongkat yang gagal diberikan padanya tersebut. Nabi Syu'aib kemudian berkata, "tongkat ini adalah tongkat titipan." Keduanya sempat saling bertengkar karena berebut tongkat tersebut sebelum seorang malaikat datang menengahi. Ia memerintahkan agar tongkat tersebut ditancapkan ke bumi. Siapapun di antara keduanya yang kuat mencabut tongkat tersebut akan menjadi pemilik tongkat dan Nabi Musa lah yang berhasil mencabutnya. ${ }^{47}$

\section{Konstruksi Pemaknaan Lafal 'Ashâ, Hayyah, Tsu'bân dan Jânn berdasarkan Teori Diksional-Leksikal Stilistika al-Qur'an: Lafal 'Ashâ (عصا)}

Dalam fragmen kisah Nabi Musa yang telah dipaparkan, ada hal yang mencolok dalam kemukjizatannya, yaitu tongkat. ${ }^{48} \mathrm{Al}$-Qur'an menggunakan lafal 'ashâ serta berbagai derivasi (sighat)nya untuk merujuk benda tersebut. Selain dalam kisah Nabi Musa, secara keseluruhan, lafal 'ashâ (

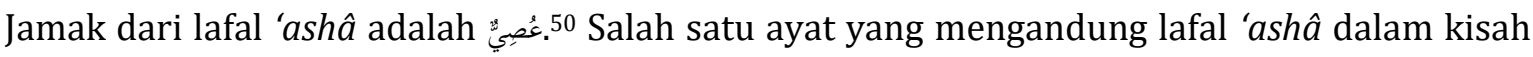
Nabi Musa adalah QS. Thâhâ [20]: 18,

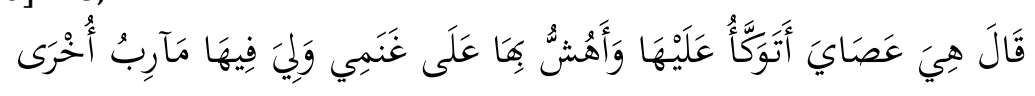

"Musa Berkata: "Ini adalah tongkatku. Aku bertelekan padanya dan aku pukul (daun) dengannya untuk kambingku. Bagiku juga ada keperluan lain padanya".

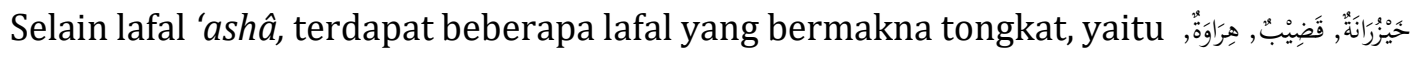

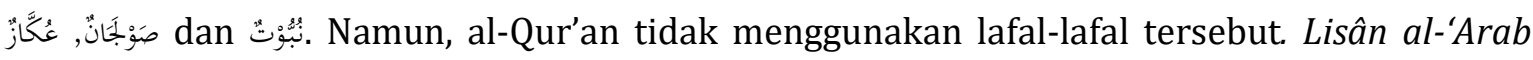
menggambarkan lafal 'ashâ sebagai kayu yang digunakan untuk memukul seekor unta ketika tidak jinak pada majikannya. Menurut Azharî, 'ashâ adalah tongkat yang keras dan kering. Ini

46 Abu Fida', Kisah Para Nabi, hlm. 487.

47 Hilmi, Nabi Musa, hlm. 66-67.

48 Tongkat yang dimiliki Nabi Musa tidak hanya dapat berubah menjadi ular, namun juga memiliki kemukjizatan membelah lautan (QS. Al-Syu'arâ' [26]: 63) dan dapat memancarkan air sebanyak 12 mata air (QS. Al-Baqarah [2]: 60 dan QS. Al-A'râf [7]: 160).

49 Al-Qur'an, al-Baqarah [2]: 60, al-A'râf [7]: 107, 117 dan 160, al-Syu 'arâ' [26]: 32, 44-45 dan 63, alNaml [27]: 10, al-Qashash [28]: 31 dan Thâhâ [20]: 18 dan 66. Muhammad Fuâd 'Abdul Bâqiy, alMu'jam al-Mufahras li alfâzh al-Qur'ân al-Karîm (Mesir: Dâr al-Kutub al-Mishrîyah, 1364), hlm. 463.

50 Ahmad Warson Munawwir, al-Munawwir Kamus Arab-Indonesia, cet-14 (Surabaya: Pustaka Progresif, 1997), hlm. 939. 
senada dengan penuturan Ibnu Barrî bahwa 'ashâ adalah tongkat yang pada dasarnya memang keras dan kokoh. ${ }^{51}$

Sementara itu, lafal 'ukkâz adalah tongkat yang ujungnya runcing atau menusuk. Biasanya, seorang lelaki menggunakannya untuk keperluan-keperluan tertentu seperti berburu sehingga 'ukkâz bisa diartikan sebagai anak panah. ${ }^{52}$ Lafal shawlajân atau shawlajânah, di sisi lain, bermakna tongkat yang kepalanya bengkok seperti tongkat dalam permainan hoki (permainan beregu yang berupaya memasukkan bola ke gawang dengan menggunakan tongkat tersebut). ${ }^{53}$

Adapun lafal qadhîb bermakna tongkat atau palang yang ada pada unta atau keledai namun tidak digunakan untuk menjinakkan keduanya. Selain itu, qadhîb juga bermakna lelaki Arab. ${ }^{54}$ Varian lain adalah lafal khayzurânah yang bermakna bambu atau rotan yang dilubangi. Menurut Ibn Sîdah, lafal ini bermakna kayu yang dikendurkan dan dihaluskan bagian luarnya untuk merayakan pesta perkembangan kemajuan negeri Arab. ${ }^{55}$ Jenis ini juga biasa digunakan untuk kayu atau tongkat dalam permainan lembing atau tombak. ${ }^{56}$

Dengan demikian, jenis sinonim kata 'ashâ dengan kata lain yang bermakna tongkat adalah sebagai berikut:

Pertama, kata 'ashâ dan nubbût merupakan jenis sinonim yang kedua, yaitu sinonim tidak total tapi komplet. Lafal nubbût dalam kamus al-Munawwir diartikan sebagai ranting atau cabang pohon, bukan batang pohon. ${ }^{57}$ Keduanya menjadi sinonim tidak total tapi komplet karena dari segi fisik, makna kedua kata tersebut memiliki kesamaan, yaitu tongkat yang terbuat dari kayu; 'ashâ, berasal dari batang pohon, sedang nubbût berasal dari cabang atau ranting pohon. Keduanya pun sama-sama digunakan sebagai tumpuan ketika berjalan dan menggembala.

Kedua, kata 'ashâ dengan khayzurânah termasuk jenis sinonim yang keempat, yaitu sinonim yang tidak total dan tidak komplet. Ini dikarenakan dari segi identitas atau makna kognitif, keduanya tidak memiliki kesamaan. Bahkan kegunaannya pun berbeda. 'Ash $\hat{a}$ digunakan untuk tumpuan sedangkan khayzurânah dipakai untuk perayaan kemajuan bangsa Arab.

Ketiga, kata 'ashâ dengan 'ukkâz; 'ashâ dengan qadhîb; dan 'ashâ dengan shawlajânah juga termasuk jenis sinonim yang keempat, yakni sinonim yang tidak total dan tidak komplet. Ketiganya tidak memiliki kemiripan dengan 'ashâ baik dari bentuk maupun kegunaan. 'Ukkâz bermakna anak panah, qadhîb bermakna palang kayu yang ada pada unta atau keledai sementara shawlajânah bermakna tongkat yang dipakai dalam permainan hoki.

Keempat, kata 'ashâ dengan hirâwah merupakan jenis sinonim yang ketiga, yakni sinonim total tapi tidak komplet. Keduanya mempunyai fungsi yang sama persis selain perihal kemukjizatan tongkat Nabi Musa. Namun demikian, dalam bentuk atau makna kognitif, masih terdapat perbedaan antara keduanya.

\footnotetext{
51 Ibnu Manzhur, Lisân al-'Arab, jilid 4, hlm. 2979.

52 Ibid., hlm. 3056.

53 Munawwir, Kamus Arab-Indonesia, hlm. 788.

${ }^{54}$ Ibnu Manzhur, Lisân al-'Arab, jilid 5, hlm. 3659.

55 Ibid., jilid 2, hlm. 1148.

56 Munawwir, Kamus Arab-Indonesia, hlm. 336.

57 Ibid., hlm. 1376.
} 
Beberapa kata tersebut menunjukkan keterkaitan dalam aspek diksional, leksikal dan makna kata. Kata 'ashâ misalnya. Kendati lafal yang bermakna tongkat bervariasi, al-Qur'an dalam kisah Nabi Musa hanya menggunakan lafal tersebut. Ini semakin menegaskan bahwa tongkat Nabi Musa terbuat dari kayu, digunakan untuk menggembala, dijadikan sebagai tumpuan ketika berjalan dan secara fisik bercabang.

Berbagai kamus menunjukkan bahwa kata 'ashâ tidak mengandung isytarâk. Ia hanya mempunyai satu makna, yaitu tongkat dengan deskripsi yang telah dijelaskan di atas. Kata tersebut merupakan kata asli yang tidak terbentuk dari kata apa pun dan inilah yang disebut dengan ism jâmid bukan musytâq. ${ }^{58}$

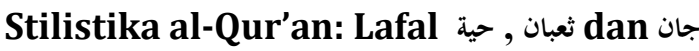

Sebagaimana dipaparkan di awal, al-Qur'an menggunakan tiga lafal yang berbeda untuk mengungkapkan makna ular dalam kisah Nabi Musa. Tiga lafal tersebut adalah dan جزان. Jânn disebutkan dalam al-Qur'an sebanyak tujuh kali, ${ }^{59}$ namun hanya dua di antaranya yang menceritakan Nabi Musa dengan redaksi yang hampir sama, yakni dalam QS. al-Naml [27]: 10 dan QS. al-Qashash [28]: 31 berikut:

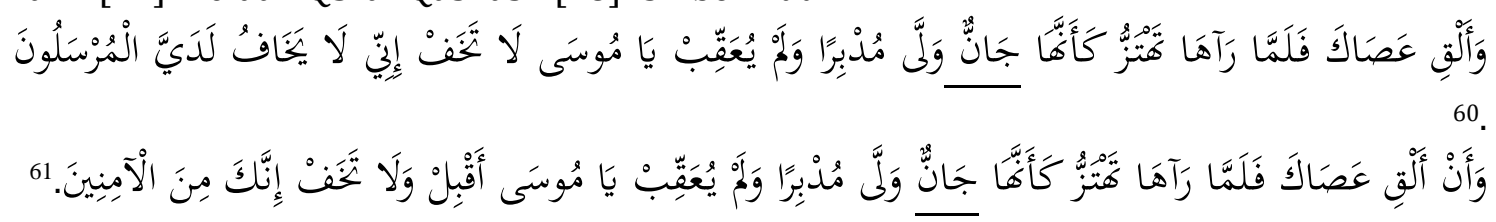

Sementar itu, tsu'bân dalam al-Qur'an disebutkan dua kali dengan redaksi yang sama persis dan hanya terdapat dalam kisah Nabi Musa, yakni dalam QS. al-A'râf [7]: 107 dan QS. al-Syu'arâ' [26]: 32 berikut:

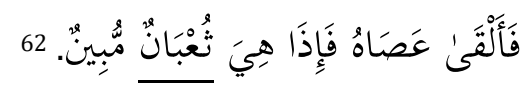

Adapun hayyah hanya disebutkan satu kali dalam al-Qur'an yakni dalam kisah Nabi Musa QS. Thâhâ [20]: 20 berikut.63

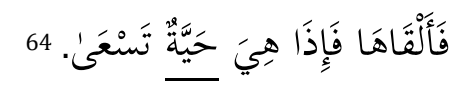

58 Isim jâmid adalah isim yang baku dan tidak diturunkan dari kata dasar. Contohnya adalah lafal sijjîl dalam QS. al-Fîl [105]: 4, sedangkan isim musytâq adalah isim yang diturunkan dari kata dasar. Contoh: lafal $m a$ 'kûl yang diturunkan dari kata $a$-ka-la. Ridhoul Wahidi, "Pola-pola Penggunaan Kata Isim dan Fi' il dalam al-Qur'an”, Jurnal 'Arabiyât, vol 1, no. 2 (Desember, 2014), hlm. 258.

${ }^{59}$ QS. al-Hijr [15]: 27, QS. al-Naml [27]: 10, QS. al-Qashash [28]: 31, QS. al-Rahmân [55]: 15, 39, 56 dan 74. Lihat, 'A6bdul Bâqiy, al-Mu'jam al-Mufahras, hlm. 179

60 Al-Qur'an, al-Naml [2667]: 10.

61 Al-Qur'an, al-Qashash [28]: 31.

${ }^{62}$ Al-Qur'an, al-A'râf [7]: 107 dan QS. al-Syu'arâ' [26]: 32.

63 'Abdul Bâqiy, al-Mu'jam al-Mufahras, hlm. 159 dan 225.

${ }^{64}$ Al-Qur'an, Thâhâ [20]: 20. 
Dalam kitab tafsir al-Jalâlayn, kata tersebut dimaknai ular yang kecil dan tangkas ( حيَّ

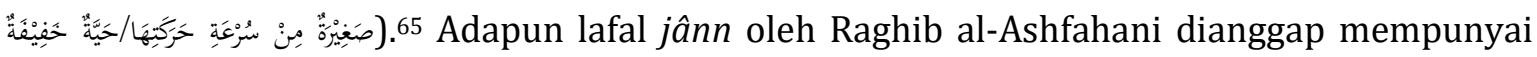
makna dasar (leksikal) tutup (satr) atau tertutupnya sesuatu dari pancaindra. ${ }^{66}$ Kata yang bermakna satr (tertutup) senada dengan peristiwa berubahnya tongkat Nabi Musa menjadi ular. Dalam peristiwa tersebut, Nabi Musa hanya berdua dengan Allah swtn dan tiada satu orang pun yang mengetahuinya. Tempatnya pun tertutup, yakni di atas bukit yang dipenuhi semak-semak. Nabi Musa bisa sampai ke bukit tersebut karena melihat cahaya api.

Kata jânn, di sisi lain, termasuk musytarak al-lafzh. Selain bermakna ular, ia juga bermakna jin. Bahkan, yang paling dominan dan sering digunakan adalah jânn yang bermakna jin dalam al-Qur'an. Di antara tujuh ayat yang menggunakan kata jânn, hanya dua ayat saja yang bermakna ular, sedangkan ayat yang lain bermakna jin.

Kata tsu'bân, sementara itu, merupakan jenis ular yang besar, gemuk serta panjang. Kata ini khususnya dipakai untuk ular yang berjenis kelamin jantan. Tsu 'bân berasal dari kata tsa'aba/intsa'aba. Makna leksikal tsa'aba adalah أَجْرَى yang artinya mengalir seperti mengalirnya air, darah dan semacamnya. Aliran yang dimaksud adalah seperti mengalirnya darah dari hidung. Terkait ini, Al-Laits menyebut bahwa aliran yang dimaksud adalah seperti air hujan ke dalam saluran air kolam. Arti lain dari tsa 'aba adalah Jَ jang juga bermakna mengalir. ${ }^{67}$

Al-Qur'an menggunakan lafal tsu'bân ketika menggambarkan momen pertemuan pertama Nabi Musa dengan Fir'aun. Ketika itu, Nabi Musa didampingi Nabi Harun. Dalam fragmen ini, al-Qur'an tidak lagi menggunakan kata jânn karena mukjizat yang berupa perubahan tongkat menjadi ular tidak lagi ditutup-tutupi, tetapi dipertontonkan di hadapan Fir'aun beserta penghuni istananya. Ular yang ada di hadapan Fir'aun ketika itu merupakan ular yang besar dan panjang. Itulah alasan penggunaan kata tsu'bân sebab ular pada kejadian tersebut mempunyai fisik panjang seperti aliran air di lembah.

Lebih jauh, kata tsu'bân tidak mengandung isytarak kendatipun merupakan turunan kata (derivasi) dari ts'aba yang bermakna mengalir. Ini dikarenakan yang disebut polisemi (musytarak al-lafzh) adalah satu kata dengan pelafalan dan ejaan yang sama tetapi dengan dua makna atau lebih. Dalam hal ini, penulis menyamakan polisemi dengan homonim, tidak dengan homofon 68 atau homograf. 69

${ }^{65}$ Jalâluddîn al-Mahallî dan Jalâluddîn al-Suyûthî, Tafsir al-Imâmayni Jalîlayni (Damaskus: Dâr Ibn Katsîr, 1407), hlm. 377 dan 389.

${ }^{66}$ Al-Râghib al-Ashfahânî, al-Mufradât fiy Gharîb al-Qur'ân (Beirut: Dâr al-Ma 'rifah, 1324), hlm. 98.

67 Ibid., hlm. 481.

${ }^{68}$ Homofon berasal dari kata homo yang artinya 'sama' dan foni yang artinya 'bunyi' atau 'suara', sehingga homofon didefinisikan sebagai kata atau istilah yang memiliki pelafalan yang sama, tetapi bentuk/ejaan (cara penulisan) serta maknanya berbeda. Contoh: sangsi - sanksi. Sangsi bermakna ekspresi yang menunjukan keraguan pada suatu hal. Sedangkan sanksi (baca: sangsi) bermakna sebuah hukuman dari suatu pelanggaran. Ratna Sumarni, 30 Contoh Kalimat Homonim, Homofon dan Homograf dalam DosenBahasa.com Ahli dan Pakar Bahasa, (Desember, 2016).

${ }^{69}$ Homograf berasal dari kata homo yang berarti 'sama' dan graf (graph) yang artinya 'tulisan', sehingga homograf didefinisikan sebagai kata atau istilah yang memiliki bentuk/ejaan (cara penulisan) sama, tetapi pengucapan atau pelafalannya berbeda. Homograf lebih mudah diidentifikasi meskipun 
Kata hayyah, di sisi lain, merupakan jenis ular beracun atau berbisa yang sudah dikenal oleh orang kebanyakan karena biasa mencelakai manusia. Lafal tersebut mencakup ular jantan dan betina. Meski demikian, menurut al-Jauharî, lafal حية hanya berlaku pada ular betina sebab ular jantan biasa menggunakan kata حي. 'Abbâs, di sisi lain, berpendapat bahwa ular berjenis hayyah mempunyai ukuran yang besarnya sama dengan ular yang berjenis tsu'bân sementara kegesitannya menyamai ular dengan jenis jânn. Selain bermakna ular, kata hayyah juga merupakan sebuah nama kabilah, yakni Hayyah ibn bahadalah. ${ }^{70}$

Sejauh penelitian penulis, kata hayyah memiliki dua makna, yaitu ular dan nama kabilah. Karenanya, kata hayyah merupakan kata yang mengandung isytarak al-lafzh meski makna yang paling banyak digunakan adalah ular. Kata hayyah sebagai nama suatu kabilah jarang sekali ditemukan, kecuali dalam kitab atau buku klasik yang masih bernuansa kehidupan orang Arab pada zaman dahulu.

Lafal tsu'bân dan hayyah merupakan lafal yang berdekatan maknanya. Keduanya termasuk jenis tarâduf yang kedua yakni syibh tarâduf (sinonim tidak total tapi komplet), karena dari segi fisik, keduanya mempunyai kesamaan, yaitu besar, gemuk dan berbisa sehingga mempunyai potensi besar mencelakai kehidupan manusia. Meski begitu, keduanya memiliki perbedaan sebab hayyah lebih gesit dan cekatan dibanding tsu 'bân.

Adapun relasi kata tsu'bân dan jânn adalah jenis tarâduf keempat, yakni sinonim yang tidak total dan tidak komplet. Ini karena tsu'bân merupakan jenis ular besar dan berbahaya sedangkan jânn merupakan ular kecil dan tidak berbahaya karena tidak berbisa. Begitu juga dengan kata jânn dan hayyah termasuk jenis sinonim yang kedua, karena dari segi fisik keduanya tidak sama namun dari segi ketangkasan, kegesitan atau kecekatan, keduanya memiliki kesamaan.

\section{Implikasi Diksional-Leksikal terhadap Makna 'Ashâ, Hayyah, Tsu'bân dan Jânn dalam Stilistika}

Diksional-leksikal merupakan dua aspek stilistika yang mempunyai pengaruh signifikan terhadap penggunaan lafal 'ashâ, tsu 'bân, jânn dan hayyah dalam kehidupan seharihari. Selain itu, kajian dua aspek ini berpengaruh terhadap kata setelah dan sebelumnya (kata sanding). Ini utamanya karena kata sanding berfungsi sebagai penjelas (bayân), sehingga lafal tersebut lebih mudah dipahami. Siyâqul kalâm dan alur dalam kisah Nabi Musa juga menjadi media yang membantu menjelaskan makna lafal tersebut.

Al-Zamakhsyari dalam tafsirnya, al-Kasyâf, sebagaimana dikutip Muhammad Hֵasan Hasan Jabal, dalam kitabnya, al-Mu'jam al-Isytiqâqî al-Muasshal li Alfâzh al-Qur'ân al-Karîm, menjelaskan ketiga lafal yang bermakna ular tersebut beserta kata sandingnya masingmasing. Kata tsu 'bân menggunakan kata sanding mubîn karena besarnya ular yang pada saat itu ditampakkan dengan jelas di hadapan Fir'aun. Adapun kata jânn menggunakan kata sanding tahtazzu karena ular jenis jânn tersebut lazimnya mempunyai gerakan yang cepat. Kemudian, kata hayyah menggunakan kata sanding tas'â karena ular tersebut berjalan jalan

tidak digabungkan dalam suatu kalimat utuh. Contoh: Mental. Mental (dengan bunyi huruf 'e' yang berbeda) bisa bermakna keadaan jiwa seseorang dan bermakna terpelanting atau terlempar karena berbenturan dengan benda lain. Lihat, ibid.

70 Ibnu Manzhur, Lisân al-'Arab, jilid 2, hlm. 1081. 
atau bergerak-gerak. Maksudnya adalah gerakan ular tersebut seperti mencari-cari sesuatu dan menampakkan kehidupannya. ${ }^{71}$

Al-Qur'an menggunakan lafal hayyah dan jânn untuk menggambarkan momen pertama perubahan tongkat Nabi Musa yang terjadi di Bukit Sinai. Ular yang dimaksud dalam sesi ini adalah hayyah, sementara jânn hanya menjadi sifat dari hayyah.72 Fragmen (adegan) ini terdapat dalam QS. Thâhâ [20]: 20, QS. al-Naml [27]: 10 dan QS. al-Qashash [28]: 31 berikut:,

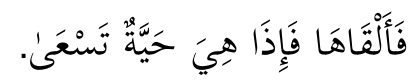

"Lalu dilemparkannyalah tongkat itu, maka tiba-tiba ia menjadi seekor ular yang merayap dengan cepat."73

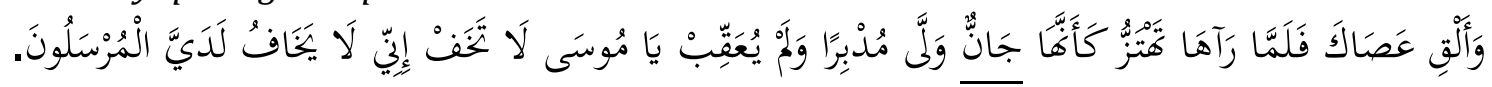

"Dan lemparkanlah tongkatmu". Maka tatkala (tongkat itu menjadi ular dan) Musa melihatnya bergerak-gerak seperti seekor ular yang gesit, larilah ia berbalik ke belakang tanpa menoleh. "Hai Musa, janganlah kamu takut. Sesungguhnya orang yang dijadikan rasul, tidak takut di hadapan-Ku."74

Perubahan kedua tongkat Nabi Musa terjadi di istana Fir'aun yang oleh al-Qur'an digambarkan dengan lafal tsu'bân. Fragmen ini terdapat dalam QS. al-A'râf [7]: 107 dan QS. al-Syu'arâ' [26]: 32,

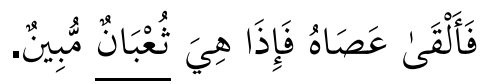

"Maka Musa menjatuhkan tongkat-nya, lalu seketika itu juga tongkat itu menjadi ular yang sebenarnya."75

Momen ketiga perubahan tongkat Nabi Musa terjadi dalam pertemuan dengan Fir'aun yang kedua kalinya, yakni dalam pertandingan antara para pesihir Fir'aun dengan Nabi Musa. Merekam momen tersebut, al-Qur'an tidak menggunakan satupun lafal-lafal yang bermakna ular. Nabi Musa hanya digambarkan mendapat perintah Allah untuk melempar tongkatnya

\footnotetext{
${ }^{71}$ Hasan Jabal, al-Mu'jam al-Isytiqâqî, hlm. 241.

72 Sebelum Allah memperlihatkan suatu kemukjizatan kepada Musa di Bukit Sinai, Allah bertanya kepada Musa perihal sesuatu yang dipegang di tangan kanannya, seperti dalam QS. Thaha [20]: 17-19,

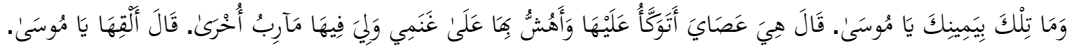

"Apakah itu yang di tangan kananmu, Hai Musa?. Berkata Musa: "Ini adalah tongkatku, aku bertelekan padanya, dan aku pukul (daun) dengannya untuk kambingku, dan bagiku ada lagi keperluan yang lain padanya". Allah berfirman: "Lemparkanlah ia, Hai Musa!"'."

Tangan kanan yang digunakan Nabi Musa untuk memegang tongkatnya mempunyai pengaruh terhadap perubahan tongkat tersebut untuk menjadi ular. Al-Razi, dalam tafsirnya, Mafâtih al-Ghaib menyebutkan bahwa tangan kanan mengandung keberkahan. Akibat keberkahan tangan kanan tersebut, maka tongkat Nabi Musa yang berada di tangan kanannya kemudian berubah menjadi ular sebagai bukti (dalil) kebenaran (petunjuk) setelah Musa melemparkannya atas perintah Allah swt. AlRazi juga menambahkan bahwa tangan kanan mengandung kemuliaan dan keberkahan (kebaikan). Fakhruddîn al-Râzî, al-Tafsîr al-Kabîr, juz 21 (Kairo: Dâr al-Fikr, 1994), hlm. 25.

${ }^{73}$ Departemen Agama, al-Qur'an dan Terjemahannya, hlm. 313.

74 Ibid., hlm. 377dan 389.

75 Ibid., hlm. 164 dan 368.
} 
yang kemudian melahap seluruh ular kecil yang merupakan tipu daya pesihir Fir'aun. Ini terekam dalam QS. Thâhâ [20]: 69 dan QS. al-A'râf [7]: 117 berikut:,

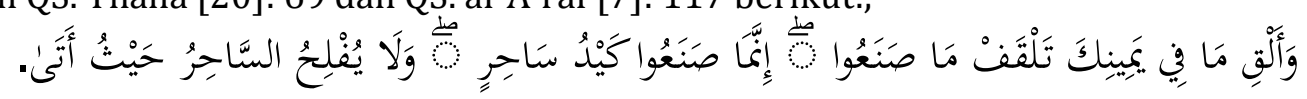

"Dan lemparkanlah apa yang ada ditangan kananmu, niscaya ia akan menelan apa yang mereka perbuat. "Sesungguhnya apa yang mereka perbuat itu adalah tipu daya tukang sihir (belaka). Dan tidak akan menang tukang sihir itu, dari mana saja ia datang."76

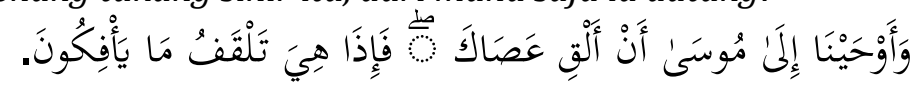

"Dan Kami wahyukan kepada Musa: "Lemparkanlah tongkatmu!". Maka sekonyongkonyong tongkat itu menelan apa yang mereka sulapkan."77

Kedua ayat di atas menunjukkan bahwa ular yang dimaksud dalam pertemuan kedua Fir'aun dengan Nabi Musa berjenis hayyah. Ini setidaknya tampak dari paparan al-Qur'an bahwa ular Nabi Musa melahap dan menelan semua tipu daya sihir dengan cepat. Sementara itu, ketakutan yang dirasakan Fir'aun, pesihir istana dan penghuni istana yang lain mengindikasikan bahwa ular Nabi Musa tersebut mempunyai fisik yang besar. Dari sini, nyaris dapat dipastikan bahwa ular Nabi Musa dalam pertandingan merupakan jenis hayyah.

Al-Qur'an lebih dahulu menggunakan kata hayyah (QS. Thâhâ) dibanding jânn (QS. alQashash). Karena itulah, penggunaan jânn yang diawali $k a$ annahâ berfungsi menjelaskan bahwa ular jenis hayyah bergerak seperti gesitnya gerakan jânn. Kata hayyah menggunakan kata sanding tas' $\hat{a}$ yang mempunyai makna 'merayap' dan ini berarti bahwa ular hayyah tidak hanya besar dan gesit, tapi juga bergerak merayap hingga menelan semua benda yang ada di hadapannya.

\section{PENUTUP}

Tongkat secara haqîqah lughawîyah merupakan sepotong bambu, rotan atau kayu yang agak panjang dan biasa digunakan untuk menopang, berjalan atau menyokong. Tongkat Nabi Musa yang diungkapkan dengan lafal 'ashâ dalam al-Qur'an pada hakikatnya adalah sebuah kayu yang berasal dari batang pohon, bersifat keras dan kokoh serta digunakan untuk berjalan atau keperluan lain. Menurut versi Ibnu Katsir, ujung tongkatnya bercabang. AlQur'an memilih lafal 'ashâ untuk menggambarkan tongkat Nabi Musa karena lafal tersebut bermakna tongkat yang kokoh, keras dan digunakan untuk berjalan, menggembala dan keperluan yang lain, seperti mengambil daun untuk memberi makan gembalaannya. Lafal 'ashâ tidak mengandung polisemi, sehingga ia tidak mempunyai makna lain selain makna tongkat.

Sementara itu, al-Qur'an memilih lafal hayyah dan jânn ketika Nabi Musa menerima maklumat kenabian dan mukjizat di Bukit Sinai. Hayyah merupakan jenis ular yang besar dan menggeliat dengan gesit, sehingga cocok dengan 'peran' ular pada kejadian tersebut. Hayyah, di sisi lain, merupakan lafal yang mengandung polisemi karena selain bermakna ular, ia juga merupakan nama kabilah. Adapun jânn adalah jenis ular yang berdesis, kecil tetapi gesit dan memiliki makna leksikal satr (tertutup). Jânn juga mengandung polisemi karena ia memiliki makna lebih dari satu yaitu ular, tertutup dan setan.

\footnotetext{
76 Departemen Agama, al-Qur'an dan Terjemahannya, hlm. 316.
}

77 Ibid., hlm. 164. 
Selain keduanya, al-Qur'an memilih lafal tsu'bân untuk menceritakan adegan ketika Nabi Musa yang didampingi Nabi Harun memperlihatkan mukjizatnya kepada Fir'aun. Ini tampak cocok mengingat tsu 'bân bermakna ular yang besar, gemuk tetapi tidak gesit. Tsu 'bân berasal dari lafal tsa'aba yang memiliki makna leksikal sâla (mengalir). Tsu'bân tidak mengandung polisemi karena ia hanya memiliki satu makna, yaitu ular.

Ketiga lafal yang memiliki makna ular tersebut mempunyai kedekatan makna. Tsu'bân-hayyah dan jânn-hayyah termasuk jenis sinonim yang tidak total tetapi komplet, sedangkan tsu 'bân-jânn termasuk jenis sinonim yang tidak total dan tidak komplet. Tsu'bânmubîn menunjukkan bahwa ular pada kejadian dimaksud terlihat jelas atau nyata di hadapan Fir'aun dan penduduk istananya. Artinya, perubahan tongkat menjadi ular tersebut tidak lagi tertutup dari pandangan manusia. Adapun hayyah-tas'â menunjukkan bahwa seekor ular yang berjalan-jalan dan menggeliat di tanah sementara tahtazzu ka annaha-jânn menunjukkan bahwa ular tersebut gesit. Penyerupaan yang mengunakan lafal ka annaha merupakan penyerupaan kegesitan hayyah seperti gesitnya jânn, sehingga lafal jânn hanya merupakan sifat gesit dari hayyah. Jadi, pemilihan diksi jânn hanya untuk menggambarkan kegesitannya saja, karena ular-ular yang berubah dari wujud tongkat Nabi Musa merupakan ular yang mempunyai fisik besar.

\section{DAFTAR PUSTAKA}

Ashfahânî, Al-Râghib. Al-Mufradât fiy Gharîb al-Qur'ân. Beirut: Dâr al-Ma'rifah. 1324.

Bâqiy, Muhammad Fuâd 'Abdul. Al-Mu'jam al-Mufahras li alfâzh al-Qur'ân al-Karîm. Mesir: Dâr al-Kutub al-Mishrîyah. 1364.

Departemen Agama. Bukhara al-Qur'an Tajwid dan Terjemah. Bandung: Sygma Examedia Arkanleema. 2010.

Departemen Pendidikan Nasional. Kamus Besar Bahasa Indonesia Pusat Bahasa. Edisi ke-4. Jakarta: Gramedia Pustaka Utama. 2008.

Hanafi, Wahyu. Ragam Gaya Bahasa Ayat-ayat Thalab dalam Diskursus Stilistika. Ponorogo: IAI Sunan Giri. 2015.

Ismâ'il, Imaduddin Abu Fida'. Kisah Para Nabi. terj. Umar Mujtahid. Cet-11. Jakarta: Ummul Qura. 2013.

Jabal, Muhammad Hasan Huasan. Al-Mu'jam al-Isytiqâqî al-Muasshal li Alfâzh al-Qur'ân alKarîm. Cet-1. Kairo: Maktabah al-Adâb. 1923.

Kattânî, 'Abd al-Haq. Al-Mughnîy: Mu'jam al-Lughah al-'Arâbiyyah. Beirut: Dâr Kutub al'Ilmiyyah. 2013.

Keraf, Gorys. Diksi dan Gaya Bahasa. Jakarta: Gramedia Pustaka Utama. 2006.

Ma'luf, Louis dan Bernard Tottel. Al-Munjid fìy al-Lughah wa al-A 'lâm. Beirut: Dâr al-Machreq. 2002.

Mahallî, Jalâluddîn dan Jalâluddîn al-Suyûthî. Tafsir al-Imâmayni Jalîlayni. Damaskus: Dâr Ibn Katsîr. 1407.

Manzhur, Ibnu. Lisân al-'Arab. Kairo: Dâr al-Ma'ârif. t.th.

Munawwir, Ahmad Warson. Al-Munawwir Kamus Arab-Indonesia. Cet-14. Surabaya: Pustaka Progresif. 1997.

Mursalim. "Gaya Bahasa Pengulangan Kisah Nabi Musa as dalam al-Qur'an: Suatu Kajian Stilistika”. Jurnal Lentera. Vol 1. Juni, 2017. 
Mustaqim, Abdul. Metode Penelitian al-Qur'an dan Tafsir. Yogyakarta: Idea Press. 2015.

Muththalib, Muhammad 'Abd. Adabîyât: al-Balâghah wa al-Ushlûbîyah. Cet-1. Mesir: alSyirkah al-Mishrîyah al-'Âlamîyah. 1994.

Muzakki, Akhmad. Stilistika al-Qur'an: Gaya Bahasa al-Qur'an dalam Konteks Komunikasi. Malang: UIN Malang. 2009.

Nasution, Ahmad Sayuti Anshari. Fonetik dan Fonologi al-Qur'an. Jakarta: Amzah. 2012.

Qalyubi, Syihabuddin. 'Ilm al-Uslûb Stilistika Bahasa dan Sastra Arab. Yogyakarta: Karya Media. 2013.

Qalyubi, Syihabuddin. Stilistika Al-Qur'an: Makna di Balik Kisah Ibrahim. Yogyakarta: LKiS. 2009.

Qalyubi, Syihabuddin. Stilistika dalam Orientasi; Studi al-Qur'an. Yogyakarta: Belukar. 2008.

Rahardjo, Mudjia dan Khalil. Sosiolinguistik Qurani. Malang: UIN Malang. 2008.

Ratna, Nyoman Kutha. Stilistika Kajian Puitika Bahasa, Sastra dan Budaya. Cet-2. Yogyakarta: Pustaka Pelajar. 2014.

Râzî, Fakhruddîn. Al-Tafsîr al-Kabîr. Kairo: Dâr al-Fikr. 1994.

Sumarni, Ratna. 30 Contoh Kalimat Homonim, Homofon dan Homograf dalam DosenBahasa.com Ahli dan Pakar Bahasa. Desember, 2016.

Suyûthî, Jalâluddîn. Al-Itqân fîy 'Ulûm al-Qur'ân. Juz 4. Tahqqîq. Abdurrahohân Fahnmî alZawawî. Kairo: Dâr al-Ghad al-Jadîd. 2006.

Zarqâni, Muhammad 'Abd al-'Azhîm. Manâhil al-'Irfân fiy 'Ulûm al-Qur'ân. Juz 1. Beirut: Dâr Ihyâ' al-Kutub al-'Ilmiyah. 2004.

Zubair. Stilistika Arab: Studi Ayat-Ayat Pernikahan dalam Al-Qur'an. Jakarta: Amzah. 2017. 